\title{
การศึกษาสภาพการบริหารจัดการเพื่อการเตรียมความพร้อมของห้องสมุด มหาวิทยาลัยในประเทศไทยสู่ประชาคมอาเซียน
}

\author{
ฐิติยา เนตรวงษ์*
}

\section{บทคัดย่อ}

การวิจัยครั้งนี้มีวัตถุประสงค์เพื่อ 1) ศึกษาและสังเคราะห์สภาพการบริหารจัดการและมาตรฐานห้องสมุด มหาวิทยาลัยในระดับภูมิภาคอาเซียน และ 2 ) ศึกษาสภาพการบริหารจัดการเพื่อการเตรียมความพร้อมของห้องสมุด มหาวิทยาลัยในประเทศไทยสู่ประชาคมอาเซียน กลุ่มตัวอย่างที่ใช้ในการศึกษาคือ ผู้บริหารห้องสมุดมหาวิทยาลัย จำนวน 5 คน กลุ่มผู้ให้บริการห้องสมุดมหาวิทยาลัยจำนวน 238 คน และกลุ่มผู้ใช้บริการห้องสมุดมหาวิทยาลัยจำนวน 942 คน วิธีการวิจัยใช้วิธีวิจัยเชิงคุณภาพและเชิงปริมาณ โดยเครื่องมือที่ใช้ในการวิจัยคือ แบบสัมภาษณ์ และ แบบสอบถาม ส่วนการวิเคราะห์ข้อมูลใช้วิธีการวิเคราะห์เนื้อหา การคำนวณหาค่าร้อยละ ค่าเฉลี่ยเลขคณิต ส่วน เบี่ยงเบนมาตรฐาน t-test และ F-test ผลการศึกษาพบว่า 1) สภาพการบริหารจัดการห้องสมุดมหาวิทยาลัยส่วนใหญ่ เริ่มมีการเตรียมความพร้อมสู่ประชาคมอาเซียน นโยบายการบริหารจัดการมาจากนโยบายของมหาวิทยาลัยแล้วระบุ เป็นพันธกิจของห้องสมุด ประเด็นการดำเนินงานเน้นการพัฒนาแหล่งเรียนรู้เพื่อรองรับการศึกษาสู่อาเซียน มาตรฐาน ของห้องสมุดต้องมีการกำหนดนโยบายการบริหารรองรับการเข้าสู่ประชาคมอาเซียน การจัดสรรงบประมาณการบริหาร และส่งเสริมกิจกรรม/โครงการรองรับประชาคมอาเซียน การเตรียมความพร้อมบุคลากร การบริการด้านการเรียนการ สอนในระดับภูมิภาคอาเซียน การบริการวิชาการและการวิจัยในระดับภูมิภาคอาเซียน การบริการสืบค้น พัฒนาเนื้อหา ดิจิทัลมากกว่าหนึ่งภาษา การจัดสภาพแวดล้อมเพื่อบรรยากาศการเรียนรู้อาเซียน มีความร่วมมือระหว่างห้องสมุดใน ระดับภูมิภาคอาเซียน และมีการประกันคุณภาพที่สอดคล้องกับนโยบายการประกันคุณภาพการบริการรองรับประชาคม อาเซียน 2) สภาพการบริหารจัดการเพื่อการเตรียมความพร้อมของห้องสมุดมหาวิทยาลัยในประเทศไทยสู่ประชาคม อาเซียนตามความคิดเห็นของกลุ่มผู้ให้บริการห้องสมุดการปฏิบัติอยู่ในระดับปานกลาง $(\bar{X}=3.33$, S.D. $=0.76)$ ผู้ ให้บริการห้องสมุดที่มีเพศ อายุ ระดับการศึกษา ลักษณะงาน และประสบการณ์การทำงานห้องสมุดต่างกัน มีการปฏิบัติ เพื่อการเตรียมความพร้อมสู่ประชาคมอาเซียนไม่แตกต่างกัน แต่ผู้ให้บริการห้องสมุดในสังกัดสถานศึกษาต่างกัน มีการ ปฏิบัติเพื่อการเตรียมความพร้อมสู่ประชาคมอาเซียนแตกต่างกัน ส่วนความคิดเห็นของกลุ่มผู้ใช้บริการห้องสมุดในการ ปฏิบัติงานของห้องสมุดอยู่ในระดับมาก $(\bar{X}=3.72$, S.D. $=0.61)$ ผู้ใช้บริการห้องสมุดที่มีเพศ อายุ และการศึกษา ต่างกัน มีความคิดเห็นต่อการปฏิบัติงานของห้องสมุดเพื่อการเตรียมความพร้อมสู่ประชาคมอาเซียนไม่แตกต่างกัน แต่ ผู้ใช้บริการห้องสมุดในสังกัดสถานศึกษาต่างกัน มีความคิดเห็นต่อการปฏิบัติของห้องสมุดเพื่อการเตรียมความพร้อมสู่ ประชาคมอาเซียนแตกต่างกัน

คำสำคัญ: การบริหารจัดการ การเตรียมความพร้อม ห้องสมุดมหาวิทยาลัย ประชาคมอาเซียน

"ผู้ช่วยศาสตราจารย์ ประจำคณะวิทยาศาสตร์และเทคโนโลยี มหาวิทยาลัยสวนดุสิต โทร. 0-2244-5630 อีเมล: titiya_net@dusit.ac.th 


\title{
The Study of the Status of Management for Readiness Preparation of University Library in Thailand to ASEAN Community
}

\author{
Titiya Netwong*
}

\begin{abstract}
The objectives of this study were: 1) to study and synthesis the status of management and standard of university library in ASEAN and 2) to study the status of management for readiness preparation of university library in Thailand to ASEAN community. The samples consisted 5 directors of university library, 238 staffs and 942 users of the university library. Research methods using qualitative research and quantitate research. The data was collected by interview form and a questionnaire. The analyzed with content analysis, percentage, mean, standard deviation, t-test and F-test. The finding of this study are as follows: 1) Management of the university library began to prepare for the ASEAN community. The management policy of university library were from the activities of the university to identify the genetic activities of the library. Operational issues on the development of learning resources to support education in ASEAN. The libraries must have a policy of support for the ASEAN community, budgeting for management and promotional activity / project support ASEAN community, personnel readiness, instructional services in the region, academic service and research in the region, service search and development of digital content in more than one language, the environment of libraries to learning atmosphere ASEAN, cooperation between libraries in the region and quality assurance compliance with the quality assurance support services of ASEAN community. 2 ) the status of management for readiness preparation of academic libraries in Thailand to ASEAN community from opinions libraries' staff were generally rated "medium" ( $\bar{X}=3.33$, S.D. $=0.76$ ), the library staffs' gender, age, education level, working character and working experiences had no effect on management for readiness preparation of academic libraries to ASEAN community whilst department of libraries made a differences in their performance, and opinions libraries' user in performance of libraries were generally rated "high" $(\bar{X}=$ 3.72, S.D. = 0.61), the library users had no different opinions on library management for readiness preparation of academic libraries to ASEAN community in relations to their gender, age and education level, on the other hand, department of libraries was the only factor that caused different opinions on the performance of academic libraries.
\end{abstract}

Keywords: management, readiness preparation, academic library, ASEAN community

\footnotetext{
* Assistant Professor, Faculty of Science and Technology, Suan Dusit University, Tel. 0-2244-5630 E-mail: titiya_net@dusit.ac.th
} 


\section{1. บทนำ}

อาเซียนเป็นภูมิภาคที่เกิดจากการรวมตัวของกลุ่ม ประเทศ 10 ประเทศคือ ไทย มาเลเซีย ฟิลิปปินส์ อินโดนีเซีย สิงคโปร์ เวียดนาม ลาว กัมพูชา พม่า และ บรูไน เพื่อสร้างความแข็งแกร่งในเวทีการเมืองและ เศรษฐกิจระหว่างประเทศ โดยผู้นำอาเซียนได้ตกลงให้มี การจัดตั้งประชาคมอาเซียนให้แล้วเสร็จภายในปี ค.ศ. 2015 (พ.ศ. 2558) ประชาคมอาเซียนประกอบด้วยความ ร่วมมือ 3 เสาหลักคือ ประชาคมการเมืองความมั่นคง อาเซียน (ASEAN Security Community: ASC) ประชาคมเศรษฐกิจอาเซียน (ASEAN Economic Community: $A E C)$ และประชาคมสังคมและวัฒนธรรม อาเซียน (ASEAN Socio-Culture Community: ASCC) [1]

ความสำคัญของการศึกษาในการขับเคลื่อนประชาคม อาเซียน เป็นสิ่งจำเป็นพื้นฐานในการสร้างอาเซียนสู่การ เป็นประชาคมที่มีความมั่นคงทั้งทางด้านเศรษฐกิจ การเมืองและสังคม การเสริมสร้างความร่วมมือกับ ประเทศเพื่อนบ้านในการพัฒนามาตรฐานการศึกษาของ สถาบันการอุดมศึกษาไปสู่ความเป็นนานาชาติ และ World Class University ตามระบบ เพื่อตอบสนองการ เปลี่ยนแปลงและความต้องการของตลาดแรงงานใน ระดับชาติและภูมิภาค การปรับตัวต่อกระแสการเปิดเสรี ทางการศึกษา และกฎบัตรอาเซียน ดังนั้นสถาบันอุดม ศึกษาไทยจึงต้องปรับตัวให้มีความพร้อมรับสถานการณ์ ที่เปลี่ยนแปลงไปหลังจากเข้าสู่ประชาคมอาเซียน [1], [2] ในการขับเคลื่อนประชาคมอาเซียนทั้ง 3 เสาหลัก สะท้อน การจัดการศึกษาแบบเชื่อมโยง การหลอมรวมความ หลากหลายบนพื้นฐานของเอกลักษณ์และความแตกต่าง การพัฒนาและประสานความร่วมมือและแลกเปลี่ยน วิชาการระหว่างชาติในภูมิภาคบนพื้นฐานของประโยชน์ ร่วมกัน

ห้องสมุดมหาวิทยาลัยเป็นหน่วยงานสังกัดสถาบัน อุดมศึกษา เป็นแหล่งเรียนรู้หลักของมหาวิทยาลัยที่ สนับสนุนการเรียนการสอนและการค้นคว้าวิจัย ตลอดจน บริการวิชาการแก่สังคมและชุมชน [2], [3] แต่จากกระแส การเปลี่ยนแปลงเพื่อการปรับตัวเข้าสู่ประชาคมอาเซียน ในปี พ.ศ. 2558 ห้องสมุดมหาวิทยาลัยในกลุ่มประเทศ
อาเซียนจึงต้องมีการปรับตัวเพื่อก้าวสู่ห้องสมุดมหาวิทยาลัย ในระดับอาเซียนให้เป็นกลไกในการขับเคลื่อนการศึกษา เพื่อรองรับการแลกเปลี่ยนการเรียนในสถาบันอุดมศึกษา ของนักศึกษาในกลุ่มประเทศอาเซียน รวมถึงเป็นเครือข่าย ห้องสมุดมหาวิทยาลัยในระดับอาเซียนและก้าวสู่ระดับโลก ต่อไป

ห้องสมุดมหาวิทยาลัยควรมีลักษณะเป็นพลวัต (Dynamic) ที่สามารถปรับเปลี่ยนได้ตามกระแสการ เปลี่ยนแปลงของโลกและในระดับภูมิภาค เพื่อส่งเสริมการ เรียนรู้และขยายโอกาสทางการศึกษา การยกระดับคุณภาพ การศึกษา [4] ดังนั้นจึงต้องมีการเตรียมความพร้อมของ ห้องสมุดทั้งในด้านมาตรฐานในระดับภูมิภาคที่สามารถ แข่งขันได้ การยกระดับการบริการ การบริหารจัดการ การ นำเทคโนโลยีสารสนเทศมาใช้ให้เกิดประโยชน์สูงสุด และ สร้างเครือข่ายความร่วมมือระหว่างห้องสมุดในระดับ ภูมิภาคอาเซียน จึงมีความจำเป็นอย่างยิ่งที่จะมีการศึกษา สภาพการบริหารจัดการเพื่อการเตรียมความพร้อมของ ห้องสมุดมหาวิทยาลัยในประเทศไทยสู่ประชาคมอาเซียน เพื่อเป็นแนวทางในการพัฒนาห้องสมุดมหาวิทยาลัยให้ ก้าวไปสู่ประชาคมอาเซียน โดยใช้แหล่งบริการการเรียนรู้ รวมถึงการใช้ประโยชน์จากห้องสมุดมหาวิทยาลัยให้ได้รับ ประโยชน์สูงสุด ส่งเสริมให้ห้องสมุดเป็นแหล่งการเรียนรู้ ตลอดชีวิตได้อย่างมีประสิทธิภาพ รวมถึงเสริมสร้างการ เรียนรู้ตลอดชีวิตให้แก่ประชาคมอาเซียนได้อีกทางหนึ่ง

\section{2. วัตถุประสงค์ของการวิจัย}

2.1 ศึกษาและสังเคราะห์สภาพการบริหารจัดการและ มาตรฐานห้องสมุดมหาวิทยาลัยในระดับภูมิภาคอาเซียน

2.2 ศึกษาสภาพการบริหารจัดการเพื่อการเตรียม ความพร้อมของห้องสมุดมหาวิทยาลัยในประเทศไทยสู่ ประชาคมอาเซียน

\section{3. สมมุติฐานของการวิจัย}

3.1 ผู้ให้บริการห้องสมุดมหาวิทยาลัยที่มีเพศ อายุ ระดับการศึกษา ลักษณะงาน ห้องสมุดในสังกัดสถาน ศึกษา และประสบการณ์การทำงานห้องสมุดต่างกัน มีการ ปฏิบัติเพื่อการเตรียมความพร้อมสู่ประชาคมอาเซียน แตกต่างกัน 
3.2 ผู้ใช้บริการห้องสมุดมหาวิทยาลัยที่มีเพศ อายุ ระดับการศึกษา และห้องสมุดในสังกัดสถานศึกษาต่างกัน มีความคิดเห็นต่อการปฏิบัติงานของห้องสมุดเพื่อการ เตรียมความพร้อมสู่ประชาคมอาเซียนแตกต่างกัน

\section{4. ขอบเขตของการวิจัย}

4.1 ประชากรที่ใช้ในการวิจัยครั้งนี้ประกอบด้วย ผู้บริหารห้องสมุดมหาวิทยาลัย ผู้ให้บริการและผู้ใช้ ห้องสมุดในประเทศไทยจำนวน 127 แห่ง

4.2 กลุ่มตัวอย่างที่ใช้ในการวิจัย คือ ผู้บริหาร ห้องสมุดมหาวิทยาลัย โดยการเลือกแบบเจาะจงจำนวน 5 คน เพื่อการสัมภาษณ์เกี่ยวกับสภาพการบริหาร จัดการและมาตรฐานห้องสมุดมหาวิทยาลัยในระดับ ภูมิภาคอาเซียน ส่วนการศึกษาการปฏิบัติงานเพื่อ เตรียมความพร้อมของห้องสมุดประกอบด้วยผู้ให้บริการ ห้องสมุดมหาวิทยาลัยจำนวน 238 คน และผู้ใช้บริการ ห้องสมุดมหาวิทยาลัยจำนวน 942 คน โดยการสุ่มแบบ เป็นกลุ่ม (Cluster sampling) คัดเลือกห้องสมุด มหาวิทยาลัยที่จะเป็นตัวแทนของแต่ละภาคจากห้องสมุด มหาวิทยาลัยในกำกับของรัฐ มหาวิทยาลัยของรัฐ มหาวิทยาลัยราชภัฏ มหาวิทยาลัยเทคโนโลยีราชมงคล และมหาวิทยาลัยเอกชน รวมทั้งสิ้น 20 สถาบัน ซึ่งขนาด ของกลุ่มผู้ใช้บริการห้องสมุดใช้สูตรของ Yamane จาก สถิติจำนวนผู้ใช้บริการโดยจำกัดจำนวนกลุ่มตัวอย่าง แต่ละแห่งต่ำสุด 45 คน

\section{3 ตัวแปรที่ศึกษาได้แก่}

4.3.1 ตัวแปรอิสระคือ ลักษณะทางประชากรศาสตร์ของผู้ให้บริการและผู้ใช้บริการห้องสมุดมหาวิทยาลัย

4.3 .2 ตัวแปรตามได้แก่ สภาพการบริหารจัดการ เพื่อการเตรียมความพร้อมของห้องสมุดมหาวิทยาลัยใน ประเทศไทยสู่ประชาคมอาเซียน 5 ประเด็นคือ มาตรฐาน ห้องสมุด การบริหารจัดการเชิงกลยุทธ์ มาตรฐานการ ให้บริการ เทคโนโลยีสารสนเทศ และเครือข่ายความร่วมมือ

4.4 ระยะเวลาดำเนินการวิจัย มีนาคม 2556 มีนาคม 2558

\section{5. วิธีดำเนินการวิจัย}

5.1 ใช้วิธีการวิจัยเชิงคุณภาพ เก็บรวบรวมข้อมูลโดย การสัมภาษณ์เชิงลึก (Indepth Interview) ผู้บริหาร ห้องสมุดมหาวิทยาลัยจำนวน 5 คน โดยใช้แบบสัมภาษณ์ เชิงลึกเกี่ยวกับสภาพการบริหารจัดการและมาตรฐาน ห้องสมุดมหาวิทยาลัยในระดับภูมิภาคอาเซียน

5.2 ใช้วิธีการวิจัยเชิงปริมาณ เก็บรวบรวมข้อมูลโดย ใช้แบบสอบถามเกี่ยวกับสภาพการบริหารจัดการเพื่อการ เตรียมความพร้อมของห้องสมุดมหาวิทยาลัยในประเทศ ไทยสู่ประชาคมอาเซียนใน 5 ประเด็นคือ มาตรฐาน ห้องสมุด การบริหารจัดการเชิงกลยุทธ์ มาตรฐานการ ให้บริการ เทคโนโลยีสารสนเทศ และเครือข่ายความ ร่วมมือ แบบสอบถามสำหรับผู้ให้บริการห้องสมุดเป็น แบบสอบถามประมาณค่า 6 ระดับคือ ปฏิบัติมากที่สุด มาก ปานกลาง น้อย น้อยที่สุด และไม่มีการปฏิบัติ มีค่าความ เชื่อมั่น เท่ากับ 0.983 ส่วนแบบสอบถามสำหรับผู้ใช้บริการ ห้องสมุดเป็นแบบสอบถามประมาณค่า 5 ระดับคือ ความ คิดเห็นเห็นด้วยมากที่สุด มาก ปานกลาง น้อย และน้อย ที่สุด มีค่าความเชื่อมั่นเท่ากับ 0.975 ทำการเก็บรวบรวม ข้อมูลจากผู้ให้บริการห้องสมุดมหาวิทยาลัยจำนวน 238 คน และผู้ใช้บริการห้องสมุดมหาวิทยาลัยจำนวน 942 คน จากห้องสมุดมหาวิทยาลัยในกำกับของรัฐ มหาวิทยาลัย ของรัฐ มหาวิทยาลัยราชภัฏ มหาวิทยาลัยเทคโนโลยีราช มงคล และมหาวิทยาลัยเอกชน จำนวนกลุ่มตัวอย่างที่เก็บ ข้อมูลรวมทั้งสิ้น 1,180 คน

5.3 วิเคราะห์ข้อมูลเชิงคุณภาพด้วยวิธีการวิเคราะห์ เนื้อหา ส่วนข้อมูลเชิงปริมาณวิเคราะห์ข้อมูลด้วยการ คำนวณหาค่าร้อยละ ค่าเฉลี่ยเลขคณิต ส่วนเบี่ยงเบน มาตรฐาน

5.4 วิเคราะห์ข้อมูลเพื่อเปรียบเทียบสภาพการบริหาร จัดการเพื่อการเตรียมความพร้อมของห้องสมุดมหาวิทยาลัย ในประเทศไทยสู่ประชาคมอาเซียนโดยใช้ t-test independent และ F-test

\section{6. ผลการวิจัย}

6.1 สภาพการบริหารจัดการห้องสมุดมหาวิทยาลัย ส่วนใหญ่เริ่มมีการเตรียมความพร้อมสู่ประชาคมอาเซียน นโยบายการบริหารจัดการมาจากนโยบายของมหาวิทยาลัย 
แล้วระบุเป็นพันธุกิจของห้องสมุด ประเด็นการดำเนินงาน เน้นการพัฒนาแหล่งเรียนรู้เพื่อรองรับการศึกษาสู่อาเซียน มาตรฐานของห้องสมุดต้องมีการกำหนดนโยบายการ บริหารรองรับการเข้าสู่ประชาคมอาเซียน การจัดสรร งบประมาณการบริหารและส่งเสริมกิจกรรม/โครงการ รองรับประชาคมอาเซียน การเตรียมความพร้อมบุคลากร การบริการด้านการเรียนการสอนในระดับภูมิภาคอาเซียน การบริการวิชาการและการวิจัยในระดับภูมิภาคอาเซียน การบริการสืบค้น พัฒนาเนื้อหาดิจิทัลมากกว่าหนึ่งภาษา การจัดสภาพแวดล้อมเพื่อบรรยากาศการเรียนรู้อาเซียน มีความร่วมมือระหว่างห้องสมุดในระดับภูมิภาคอาเซียน และมีการประกันคุณภาพที่สอดคล้องกับนโยบายการ ประกันคุณภาพการบริการรองรับประชาคมอาเซียน

จากการสังเคราะห์การบริหารจัดการห้องสมุด มหาวิทยาลัยในประเทศไทยสู่ประชาคมอาเซียนมี 5 ประเด็นคือ

1) มาตรฐานห้องสมุดในประเทศไทยสู่ประชาคม อาเซียนต้องมีองค์ประกอบด้านการบริหารจัดการ การ ให้บริการ ความพร้อมของบุคลากรห้องสมุด ทรัพยากร สารสนเทศ การจัดการทรัพยากรสารสนเทศและคลัง ความรู้ และเครือข่ายความร่วมมือระหว่างห้องสมุด

2) การบริหารจัดการเชิงกลยุทธ์ต้องมีการวิเคราะห์ ปัจจัยภายในและปัจจัยภายนอกเพื่อใช้ในการวางแผน กำหนดยุทธศาสตร์ และดำเนินงานการขับเคลื่อนสู่ ประชาคมอาเซียน

3) มาตรฐานการให้บริการต้องมีรูปแบบบริการเชิง รุก มุ่งสู่ความเป็นเลิศ

4) เทคโนโลยีสารสนเทศ เว็บไซต์และบริการ OPAC ภาษาอังกฤษและภาษาภูมิภาคอาเซียนเทคโนโลยีการ บริการรองรับการเข้าถึงได้ทุกอุปกรณ์และทุกโปรแกรม

5) เครือข่ายความร่วมมือ เป็นการสร้างเครือข่าย ความร่วมมือเพื่อประโยชน์ในการพัฒนาบุคลากร ห้องสมุด การแบ่งปันทรัพยากรสารสนเทศ การใช้ เทคโนโลยี ความร่วมมือในการดำเนินกิจกรรมห้องสมุด

6.2 สภาพการบริหารจัดการเพื่อการเตรียมความ พร้อมของห้องสมุดมหาวิทยาลัยในประเทศไทยสู่ประชาคม อาเซียนตามความคิดเห็นของกลุ่มผู้ให้บริการห้องสมุด การปฏิบัติอยู่ในระดับปานกลาง $(\bar{X}=3.33$, S.D. $=$
0.76) ส่วนความคิดเห็นของกลุ่มผู้ใช้บริการห้องสมุดใน การปฏิบัติงานของห้องสมุดอยู่ในระดับมาก $(\bar{X}=3.72$, S.D. $=0.61)$ รายละเอียดดังตารางที่ 1 และ 2

ตารางที่ 1 การบริหารจัดการเพื่อการเตรียมความพร้อม ของห้องสมุดมหาวิทยาลัยสู่ประชาคม อาเซียนของกลุ่มผู้ให้บริการ

\begin{tabular}{l|c|c|c}
\hline \hline \multicolumn{1}{c|}{ รายการ } & $\overline{\mathrm{X}}$ & S.D. & $\begin{array}{c}\text { ระดับการ } \\
\text { ปฏิบัติ }\end{array}$ \\
\hline มาตรฐานห้องสมุด & 3.26 & 0.85 & ปานกลาง \\
\hline การบริหารจัดการเชิงกลยุทธ์ & 3.27 & 0.93 & ปานกลาง \\
\hline มาตรฐานการให้บริการ & 3.44 & 0.78 & ปานกลาง \\
\hline เทคโนโลยีสารสนเทศ & 3.36 & 0.85 & ปานกลาง \\
\hline เครือข่ายความร่วมมือ & 3.33 & 0.91 & ปานกลาง \\
\hline \multicolumn{1}{c|}{ ภาพรวม } & $\mathbf{3 . 3 3}$ & $\mathbf{0 . 7 6}$ & ปานกลาง \\
\hline \hline
\end{tabular}

จากตารางที่ 1 การบริหารจัดการเพื่อการเตรียม ความพร้อมของห้องสมุดมหาวิทยาลัยสู่ประชาคม อาเซียนของกลุ่มผู้ให้บริการ การปฏิบัติในภาพรวมอยู่ใน ระดับปานกลาง $(\bar{X}=3.33$, S.D. $=0.76)$ เมื่อพิจารณา รายด้านทุกด้านการปฏิบัติอยู่ในระดับปานกลาง โดย มาตรฐานการให้บริการมีการปฏิบัติในลำดับแรก $(\overline{\mathrm{X}}=$ 3.44, S.D. $=0.78$ )

ตารางที่ 2 การบริหารจัดการเพื่อการเตรียมความพร้อม ของห้องสมุดมหาวิทยาลัยสู่ประชาคมอาเซียน ตามความคิดเห็นของผู้ใช้บริการ

\begin{tabular}{l|c|c|c}
\hline \hline \multicolumn{1}{c|}{ รายการ } & $\overline{\mathrm{X}}$ & S.D. & $\begin{array}{c}\text { ระดับความ } \\
\text { คิดเห็น }\end{array}$ \\
\hline มาตรฐานห้องสมุด & 3.76 & 0.62 & มาก \\
\hline การบริหารจัดการเชิงกลยุทธ์ & 3.62 & 0.69 & มาก \\
\hline มาตรฐานการให้บริการ & 3.77 & 0.65 & มาก \\
\hline เทคโนโลยีสารสนเทศ & 3.69 & 0.70 & มาก \\
\hline เครือข่ายความร่วมมือ & 3.71 & 0.71 & มาก \\
\hline \multicolumn{1}{c|}{ ภาพรวม } & $\mathbf{3 . 7 2}$ & $\mathbf{0 . 6 1}$ & มาก \\
\hline \hline
\end{tabular}

จากตารางที่ 2 การบริหารจัดการเพื่อการเตรียม ความพร้อมของห้องสมุดมหาวิทยาลัยสู่ประชาคมอาเซียน ตามความคิดเห็นของผู้ใช้บริการภาพรวมความคิดเห็น อยู่ระดับมาก $(\bar{X}=3.72$, S.D. $=0.61)$ เมื่อพิจารณา รายด้านทุกด้านความคิดเห็นอยู่ในระดับมาก โดย มาตรฐานการให้บริการมีความคิดเห็นในลำดับแรก $(\overline{\mathrm{X}}$ $=3.77$, S.D. $=0.65$ ) 
6.3 การวิเคราะห์เปรียบเทียบสภาพการบริหาร จัดการเพื่อการเตรียม ความพร้อมของห้องสมุด มหาวิทยาลัยในประเทศไทยสู่ประชาคมอาเซียน

การเปรียบเทียบสภาพการบริหารจัดการเพื่อการ เตรียมความพร้อมของห้องสมุดมหาวิทยาลัยสู่ประชาคม อาเซียนจำแนกตามเพศ อายุ ระดับการศึกษา ลักษณะ งาน ห้องสมุดในสังกัดสถานศึกษา และประสบการณ์ การทำงานห้องสมุด ของผู้ให้บริการห้องสมุด มี รายละเอียดดังตารางที่ $3-6$

ตารางที่ 3 เปรียบเทียบสภาพการบริหารจัดการเพื่อการ เตรียมความพร้อมของห้องสมุดมหาวิทยาลัย สู่ประชาคมอาเซียนจำแนกตามเพศ

\begin{tabular}{c|c|c|c|c|c|c}
\hline \hline \multirow{2}{*}{$\begin{array}{c}\text { สภาพการ } \\
\text { บริหารจัดการฯ }\end{array}$} & \multicolumn{2}{|c|}{ เพศชาย } & \multicolumn{2}{|c|}{ เพศหญิง } & $\mathbf{t}$ & $\mathbf{p}$ \\
\cline { 2 - 5 } & $\overline{\mathrm{X}}$ & S.D. & $\overline{\mathrm{X}}$ & S.D. & & \\
\hline ภาพรวม & 3.22 & 0.71 & 3.37 & 0.77 & 0.43 & 0.51 \\
\hline \hline
\end{tabular}

*มีระดับนัยสำคัญทางสถิติที่ระดับ .05

จากตารางที่ 3 ผู้ให้บริการห้องสมุดที่มีเพศต่างกัน สภาพการบริหารจัดการเพื่อการเตรียมความพร้อมของ ห้องสมุดมหาวิทยาลัยสู่ประชาคมอาเซียนไม่แตกต่างกัน ตารางที่ 4 เปรียบเทียบสภาพการบริหารจัดการจำแนก ตามอายุ ระดับการศึกษา ห้องสมุดในสังกัด สถานศึกษา และประสบการณ์การทำงาน ห้องสมุด

\begin{tabular}{c|c|c|c|c|c|c}
\hline \hline $\begin{array}{c}\text { การบริหาร } \\
\text { จัดการ }\end{array}$ & $\begin{array}{c}\text { แหล่งความ } \\
\text { แปรปรวน }\end{array}$ & Df & SS & MS & F & p \\
\hline \multirow{4}{*}{ อายุ } & ระหว่างกลุ่ม & 4 & 1.84 & 0.46 & 0.79 & 0.52 \\
\cline { 2 - 7 } & ภายในกลุ่ม & 233 & 134.75 & 0.57 & & \\
\cline { 2 - 7 } & รวม & 237 & 136.60 & & & \\
\hline ระดับการศึกษา & ระหว่างกลุ่ม & 3 & 3.66 & 1.22 & 2.15 & 0.09 \\
\cline { 2 - 7 } & ภายในกลุ่ม & 234 & 132.93 & 0.56 & & \\
\cline { 2 - 7 } & รวม & 237 & 136.60 & & & \\
\hline \multirow{2}{*}{ ห้องสมุดในสังกัด } & ระหว่างกลุ่ม & 4 & 14.86 & 3.71 & 7.11 & $0.00^{*}$ \\
\cline { 2 - 7 } & ภายในกลุ่ม & 233 & 121.74 & 0.52 & & \\
\cline { 2 - 7 } & รวม & 237 & 136.60 & & & \\
\hline ประสบการณ์ย & ระหว่างกลุ่ม & 4 & 1.84 & 0.46 & 0.79 & 0.52 \\
\cline { 2 - 7 } & ภายในกลุ่ม & 233 & 134.75 & 0.57 & & \\
\cline { 2 - 7 } & รวม & $\mathbf{2 3 7}$ & $\mathbf{1 3 6 . 6 0}$ & & & \\
\hline \hline
\end{tabular}

*มีระดับนัยสำคัญทางสถิติที่ระดับ .05

จากตารางที่ 4 ผู้ให้บริการห้องสมุดที่มีอายุ ระดับการ ศึกษา และประสบการณ์การทำงานห้องสมุดต่างกัน มี
สภาพการบริหารจัดการเพื่อการเตรียมความพร้อมของ ห้องสมุดมหาวิทยาลัยสู่ประชาคมอาเซียนไม่แตกต่างกัน แต่ผู้ให้บริการห้องสมุดที่ห้องสมุดในสังกัดสถานศึกษา ต่างกัน มีสภาพการบริหารจัดการเพื่อการเตรียมความ พร้อมของห้องสมุดมหาวิทยาลัยสู่ประชาคมอาเซียนต่างกัน ตารางที่ 5 เปรียบเทียบค่าเฉลี่ยสภาพการบริหารจัดการ เป็นรายคู่ด้วยวิธี LSD จำแนกตามห้องสมุด ในสังกัดสถานศึกษาของผู้ให้บริการห้องสมุด

\begin{tabular}{c|c|c|c|c|c|c}
\hline \hline $\begin{array}{c}\text { ห้องสมุด } \\
\text { ในสังกัด }\end{array}$ & $\bar{X}$ & 1 & 2 & 3 & 4 & 5 \\
\cline { 3 - 7 } & 3.48 & 3.06 & 3.62 & 3.10 & 3.04 \\
\hline 1 & 3.48 & - & $0.41^{*}$ & -0.14 & $0.37^{*}$ & $0.43^{*}$ \\
\hline 2 & 3.06 & & - & $-0.55^{*}$ & -0.04 & 0.02 \\
\hline 3 & 3.62 & & & - & $0.51^{*}$ & $0.57^{\star}$ \\
\hline 4 & 3.10 & & & & - & 0.06 \\
\hline 5 & 3.04 & \multicolumn{3}{|l|}{} & - \\
\hline \hline
\end{tabular}

หมายเหตุ ห้องสมุดในสังกัดสถานศึกษา 1. มหาวิทยาลัยในกำกับ ของรัฐ 2. มหาวิทยาลัยของรัฐ 3 . มหาวิทยาลัยราชภัฏ 4. มหาวิทยาลัยเทคโนโลยีราชมงคล 5 . มหาวิทยาลัยและสถาบัน เอกชน

จากตารางที่ 5 สภาพการบริหารจัดการเพื่อการเตรียม ความพร้อมของห้องสมุดมหาวิทยาลัยมหาวิทยาลัยใน กำกับของรัฐมีการปฏิบัติมากกว่าห้องสมุดมหาวิทยาลัย ของรัฐ และมหาวิทยาลัยเทคโนโลยีราชมงคล โดยมีผลต่าง ของค่าเฉลี่ยการปฏิบัติเท่ากับ 0.41 และ 0.37 ตามลำดับ นอกจากนี้สภาพการบริหารจัดการเพื่อการเตรียมความ พร้อมของห้องสมุดมหาวิทยาลัยราชภัฏมีการปฏิบัติ มากกว่าห้องสมุดห้องสมุดมหาวิทยาลัยของรัฐ มหาวิทยาลัย เทคโนโลยีราชมงคล และ.มหาวิทยาลัยและสถาบันเอกชน โดยมีผลต่างของค่าเฉลี่ยการปฏิบัติเท่ากับ $0.55,0.51$ และ 0.57 ตามลำดับ

ตารางที่ 6 เปรียบเทียบสภาพการบริหารจัดการเพื่อการ เตรียมความพร้อมของห้องสมุดมหาวิทยาลัย สู่ประชาคมอาเซียนจำแนกตามลักษณะงาน

\begin{tabular}{c|c|c|c|c|c|c}
\hline \hline \multirow{2}{*}{$\begin{array}{c}\text { สภาพการ } \\
\text { บริหารจัดการฯ }\end{array}$} & \multicolumn{2}{|c|}{ ผู้บริหาร } & \multicolumn{2}{|c|}{ ผู้ปฏิบัติ } & \multirow{2}{*}{$\mathrm{t}$} & $\mathrm{p}$ \\
\cline { 2 - 5 } & $\overline{\mathrm{X}}$ & S.D. & $\overline{\mathrm{X}}$ & S.D. & & \\
\hline ภาพรวม & 3.23 & 0.82 & 3.35 & 0.75 & 0.53 & 0.46 \\
\hline \hline
\end{tabular}

*มีระดับนัยสำคัญทางสถิติที่ระดับ .05

จากตารางที่ 6 ผู้ให้บริการห้องสมุดที่มีลักษณะงาน ต่างกัน มีสภาพการบริหารจัดการเพื่อการเตรียมความ 
พร้อมของห้องสมุดมหาวิทยาลัยสู่ประชาคมอาเซียนไม่ แตกต่างกัน

การเปรียบเทียบความคิดเห็นสภาพการบริหาร จัดการเพื่อการเตรียม ความ พร้อมของห้องสมุด มหาวิทยาลัยสู่ประชาคมอาเซียนของผู้ใช้บริการ ห้องสมุดที่มีรายละเอียดดังตารางที่ $7-9$

ตารางที่ 7 เปรียบเทียบความคิดเห็นสภาพการบริหาร จัดการเพื่อการเตรียม ความพร้อมของ ห้องสมุดมหาวิทยาลัยสู่ประชาคมอาเซียน จำแนกตามเพศ

\begin{tabular}{c|c|c|c|c|c|c}
\hline \hline $\begin{array}{c}\text { ความคิดเห็น } \\
\text { สภาพการ } \\
\text { บริหารจัดการy }\end{array}$ & \multicolumn{2}{|c|}{ เพศชาย } & \multicolumn{2}{|c|}{ เพศหญิง } & $\mathrm{t}$ & $\mathrm{p}$ \\
\cline { 2 - 5 } & $\overline{\mathrm{X}}$ & S.D. & $\overline{\mathrm{X}}$ & $\mathrm{S} . \mathrm{D}$. & & \\
\hline ภาพรวม & 3.67 & 0.63 & 3.75 & 0.60 & 1.31 & 0.25 \\
\hline \hline
\end{tabular}

*มีระดับนัยสำคัญทางสถิติที่ระดับ .05

จากตารางที่ 7 ผู้ใช้บริการห้องสมุดที่มีเพศต่างกัน มีความคิดเห็นต่อสภาพการบริหารจัดการเพื่อการ เตรียม ความพร้อมของห้องสมุดมหาวิทยาลัยสู่ ประชาคมอาเซียนไม่แตกต่างกัน

ตารางที่ 8 เปรียบเทียบความคิดเห็นสภาพการบริหาร จัดการเพื่อการเตรียม ความพร้อมของ ห้องสมุดมหาวิทยาลัยในประเทศไทยสู่ ประชาคมอาเซียนจำแนกตามอายุ ระดับ การศึกษา และห้องสมุดในสังกัดสถานศึกษา

\begin{tabular}{|c|c|c|c|c|c|c|}
\hline $\begin{array}{c}\text { การบริหาร } \\
\text { จัดการฯ }\end{array}$ & $\begin{array}{l}\text { แหล่งความ } \\
\text { แปรปรวน }\end{array}$ & Df & ss & MS & $\mathbf{F}$ & p \\
\hline \multirow[t]{3}{*}{ อายุ } & ระหว่างกลุ่ม & 3 & 1.58 & 0.52 & 1.42 & 0.23 \\
\hline & ภายในกลุ่ม & 938 & 348.44 & 0.37 & & \\
\hline & รวม & 941 & 350.03 & & & \\
\hline \multirow[t]{3}{*}{ การศึกษา } & ระหว่างกลุ่ม & 3 & 2.38 & 0.79 & 2.10 & 0.09 \\
\hline & ภายในกลุ่ม & 938 & 347.64 & 0.37 & & \\
\hline & รวม & 941 & 350.03 & & & \\
\hline \multirow{3}{*}{$\begin{array}{l}\text { ห้องสมุด } \\
\text { ในสังกัดข }\end{array}$} & ระหว่างกลุ่ม & 4 & 9.10 & 2.27 & 6.25 & $0.00^{*}$ \\
\hline & ภายในกลุ่ม & 937 & 340.92 & 0.36 & & \\
\hline & รวม & 941 & 350.03 & & & \\
\hline
\end{tabular}

*มีระดับนัยสำคัญทางสถิติที่ระดับ .05

จากตารางที่ 8 ผู้ใช้บริการห้องสมุดที่มี อายุ และ การศึกษาต่างกัน มีความคิดเห็นต่อการปฏิบัติของ ห้องสมุดเพื่อการเตรียมความพร้อมสู่ประชาคมอาเซียน ไม่แตกต่างกัน แต่ผู้ใช้บริการห้องสมุดในสังกัดสถาน
ศึกษาต่างกัน มีความคิดเห็นต่อการปฏิบัติของห้องสมุด เพื่อการเตรียมความพร้อมสู่ประชาคมอาเซียนแตกต่างกัน ตารางที่ 9 เปรียบเทียบความคิดเห็นค่าเฉลี่ยสภาพการ บริหารจัดการเป็นรายคู่ด้วยวิธี LSD จำแนก ตามห้องสมุดในสังกัดสถานศึกษาของผู้ใช้ บริการห้องสมุด

\begin{tabular}{c|c|c|c|c|c|c}
\hline \hline $\begin{array}{c}\text { ห้องสมุด } \\
\text { ในสังกัด }\end{array}$ & $\bar{X}$ & 1 & 2 & 3 & 4 & 5 \\
\cline { 3 - 7 } & & 3.70 & 3.65 & 3.87 & 3.65 & 3.63 \\
\hline 1 & 3.70 & - & 0.05 & $-0.17^{*}$ & 0.05 & 0.06 \\
\hline 2 & 3.65 & & - & $-0.22^{*}$ & -0.01 & 0.02 \\
\hline 3 & 3.87 & & & - & $0.22^{*}$ & $0.23^{*}$ \\
\hline 4 & 3.65 & & & & - & 0.02 \\
\hline 5 & 3.63 & & & & & - \\
\hline \hline
\end{tabular}

หมายเหตุ ห้องสมุดในสังกัดสถานศึกษา 1. มหาวิทยาลัยในกำกับ ของรัฐ 2. มหาวิทยาลัยของรัฐ 3 . มหาวิทยาลัยราชภัฏ 4 . มหาวิทยาลัยเทคโนโลยีราชมงคล 5 . มหาวิทยาลัยและสถาบัน เอกชน

จากตารางที่ 9 สภาพการบริหารจัดการเพื่อการเตรียม ความพร้อมของห้องสมุดมหาวิทยาลัยราชภัฏมีการปฏิบัติ มากกว่าห้องสมุดมหาวิทยาลัยในกำกับของรัฐ ห้องสมุด มหาวิทยาลัยของรัฐ มหาวิทยาลัยเทคโนโลยีราชมงคล และ.มหาวิทยาลัยและสถาบันเอกชน โดยมีผลต่างของ ค่าเฉลี่ยการปฏิบัติเท่ากับ $0.17 \quad 0.22 \quad 0.22$ และ 0.23 ตามลำดับ

\section{7. สรุปและอภิปรายผล}

7.1 สภาพการบริหารจัดการห้องสมุดมหาวิทยาลัย ส่วนใหญ่เริ่มมีการเตรียมความพร้อมสู่ประชาคมอาเซียน นโยบายการบริหารจัดการมาจากนโยบายของมหาวิทยาลัย แล้วระบุเป็นพันธกิจของห้องสมุด ประเด็นการดำเนินงาน เน้นการพัฒนาแหล่งเรียนรู้เพื่อรองรับการศึกษาสู่อาเซียน สอดคล้องกับผลการวิจัยของจุฑารัตน์ และเปี่ยมสุข [2] ที่ พบว่าห้องสมุดมหาวิทยาลัยบางแห่งมีการเตรียมความ พร้อมที่จะเข้าสู่ประชาคมอาเซียนอย่างเป็นรูปธรรมและ ชัดเจน เพราะเป็นนโยบายในระดับมหาวิทยาลัยห้องสมุด จึงต้องนำมาปฏิบัติ นอกจากนี้การบริหารจัดการยังต้อง พิจารณาถึงพื้นฐานความเข้าใจในบริบทของการเปลี่ยนแปลง ที่จะเกิดขึ้น มีการผลักดันและความต้องการขับเคลื่อน ร่วมกันให้บริหารจัดการประสบความสำเร็จ $[5]$ สำหรับ 
มาตรฐานห้องสมุดที่สำคัญเพื่อเตรียมความพร้อมสู่ ประชาคมอาเซียนคือการเตรียมความพร้อมบุคลากร โดยเฉพาะอย่างยิ่งด้านภาษา อังกฤษเพราะห้องสมุดทุก ที่ให้ความสำคัญกับการอบรมพัฒนาบุคลากรด้าน ภาษาอังกฤษจะเห็นได้จากแผน ปฏิบัติราชการสำนัก วิทยบริการและเทคโนโลยีสารสนเทศ [6] หลายแห่ง มี การระบุเป็นลายลักษณ์อักษรและจัดสรรงบประมาณเพื่อ เพิ่มศักยภาพด้านภาษาต่างประเทศ มีการจัดกิจกรรม/ โครงการเพื่อพัฒนาบุคลากรด้านภาษาเพื่อรองรับการ เรียนรู้และการให้ บริการเช่น อบรมภาษาต่างประเทศ สำหรับบุคลากร ค่ายภาษาอังกฤษ ภาษาจีน เป็นต้น ใน การบริการด้านการเรียนการสอนและการวิจัยของ ห้องสมุดเพื่อยกระดับการบริการในระดับภูมิภาค อาเซียน ห้องสมุดส่วนใหญ่มีการพัฒนาทรัพยากร สารสนเทศให้อยู่ในรูปแบบสื่อดิจิทัล บริการรูปแบบ เครือข่ายฐานข้อมูลและการเรียนการสอนแบบออนไลน์ที่ ครอบคลุมการเรียนรู้และการวิจัยสอดคล้องกับแนวคิด ของกุลธิดา จุฑารัตน์ และกันยารัตน์ [7] ที่นำเสนอว่า การให้บริการของห้องสมุดต้องเน้นการเข้าถึงสารสนเทศ โดยใช้เทคโนโลยีสารสนเทศในการเข้าถึง คนทำงานวิจัย เลือกที่จะสืบค้นและใช้สารสนเทศออนไลน์เป็นอันดับ แรก ห้องสมุดจำเป็นต้องจัดหาทรัพยากรสารสนเทศที่มี ความหลากหลาย และเหมาะสมกับบุคคลประเภทต่าง ๆ นอกจากนี้ยังสอดคล้องกับแผนยุทธศาสตร์ห้องสมุดปี ค.ศ. 2020 ของห้องสมุดแห่งชาติสิงคโปร์ที่ระบุว่า ห้องสมุดจะต้องปรับตัวให้เข้ากับเทคโนโลยีใหม่ ๆ ที่ เกิดขึ้นอย่างรวดเร็ว การเข้าถึงแหล่งห้องสมุดดิจิทัลและ การบริการให้ผู้ใช้ห้องสมุดสามารถเข้าถึงและเชื่อมต่อ การรบริการดิจิทัล [8]

7.2 สภาพการบริหารจัดการเพื่อการเตรียมความ พร้อมของห้องสมุดมหาวิทยาลัยสู่ประชาคมอาเซียน ของกลุ่มผู้ให้บริการมีการปฏิบัติอยู่ในระดับปานกลาง แต่ความคิดเห็นของกลุ่มผู้ใช้บริการห้องสมุดมีความ คิดเห็นอยู่ในระดับมาก อาจเนื่องจากกลุ่มผู้ใช้ได้รับการ ตอบสนองการให้บริการในระดับที่น่าพอใจจึงมีความ คิดเห็นว่าการดำเนินงานหรือการบริหารจัดการเพื่อการ เตรียมความพร้อมสู่ประชาคมอาเซียนของห้องสมุดอยู่ ในระดับที่มีการดำเนินการอยู่ในระดับมาก เมื่อพิจารณา
รายด้านพบว่า มาตรฐานการให้บริการอยู่ในลำดับแรกที่มี การปฏิบัติซึ่งสอดคล้องกันทั้งสองกลุ่ม จึงอาจกล่าวได้ว่า ห้องสมุดมหาวิทยาลัยให้ความสำคัญต่อการให้บริการมาก ที่สุด สอดคล้องกับแนวคิดที่ว่า ห้องสมุดมีบทบาทสำคัญ ในการสร้างให้เกิดการเรียนรู้ตลอดชีวิต ห้องสมุดเป็นแหล่ง ความรู้ที่ทุกคนสามารถเข้าถึงได้อย่างเท่าเทียมกัน และ ยังคงทำหน้าที่ส่งเสริมการแลกเปลี่ยนความรู้ให้แก่กันและ กันต่อไป [8] เมื่อเปรียบเทียบสภาพการบริหารจัดการเพื่อ การเตรียมความพร้อมของห้องสมุดมหาวิทยาลัยสู่ประชาคม อาเซียนของผู้ให้บริการห้องสมุดที่มีเพศ อายุ ระดับการ ศึกษา ลักษณะงาน และประสบการณ์การทำงานห้องสมุด ต่างกัน มีการปฏิบัติเพื่อการเตรียมความพร้อมสู่ประชาคม อาเซียนไม่แตกต่างกัน แต่ผู้ให้บริการห้องสมุด ที่มีห้องสมุด ในสังกัดสถานศึกษาต่างกัน มีการปฏิบัติเพื่อการเตรียม ความพร้อมสู่ประชาคมอาเซียนแตกต่างกัน สาเหตุที่ ห้องสมุดในสังกัดสถานศึกษาต่างกันผู้ให้บริการห้องสมุดมี การปฏิบัติต่างกัน โดยเฉพาะอย่างยิ่งห้องสมุดของ มหาวิทยาลัยในกำกับของรัฐและห้องสมุดของมหาวิทยาลัย ราชภัฏจะดำเนินการมากที่สุดอาจเนื่องจากการกำหนด นโยบายระดับมหาวิทยาลัยแล้วลงสู่ห้องสมุด และได้มีการ จัดสรรงบประมาณเพื่อเตรียมความพร้อมเข้าสู่ประชาคม อาเซียน มีการกำหนดนโยบายอย่างชัดเจน เป็นรูปธรรม และเป็นลายลักษณ์อักษร [2], [6] เมื่อพิจารณาเปรียบเทียบ ความคิดเห็นการบริหารจัดการเพื่อการเตรียมความพร้อม ของห้องสมุดมหาวิทยาลัยสู่ประชาคมอาเซียนของผู้ใช้ บริการห้องสมุดที่มีเพศ อายุ และการศึกษาต่างกัน มีความ คิดเห็นต่อการปฏิบัติงานของห้องสมุดเพื่อการเตรียมความ พร้อมสู่ประชาคมอาเซียนไม่แตกต่างกัน แต่ผู้ใช้บริการ ห้องสมุดในสังกัดสถานศึกษาต่างกัน มีความคิดเห็นต่อ การปฏิบัติของห้องสมุดเพื่อการเตรียมความพร้อมสู่ ประชาคมอาเซียนแตกต่างกัน สอดคล้องกับกลุ่มผู้ให้ บริการห้องสมุด และอาจเนื่องจาก ห้องสมุดในสถานศึกษา ต่างกันย่อมมีความต้องการบริการที่แตกต่างกัน ส่งผลให้ ความคิดเห็นต่อมาตรฐานการให้บริการห้องสมุด การ บริหารจัดการห้องสมุดเพื่อการเตรียมความพร้อมสู่ ประชาคมอาเซียนแตกต่างกัน 
9. เอกสารอ้างอิง

[1] กระทรวงศึกษาธิการ. (ม.ป.ป). การศึกษา : การสร้าง ประชาคมอาเซียน 2558. กรุงเทพย : สำนักงาน ปลัดกระทรวงศึกษาธิการ กระทรวงศึกษาธิการ.

[2] จุฑารัตน์ ศราวณะวงศ์ และเปี่ยมสุข ทุ่งกาวี. (2556). การปรับตัวของห้องสมุดมหาวิทยาลัย ไทยในการส่งเสริมการเรียนรู้เพื่อรองรับการเข้า สู่ประชาคมอาเซียน. การประชุมวิชาการนิเทศศาสตร์ และสารสนเทศศาสตร์แห่งชาติ ครั้งที่ 1 วันที่ 14 สิงหาคม 2556 .

[3] สุนีย์ กาศจำรูญ. (2547). ความรู้เบื้องต้นเกี่ยวกับ การจัดการหน่วยงานบริการสารสนเทศ. ภาควิชา บรรณารักษศาสตร์ คณะมนุษยศาสตร์ มหาวิทยาลัย รามคำแหง.

[4] สำนักงานคณะกรรมการการอุดมศึกษา. (2553). ผลงานที่นำเสนอในการสัมมนา PULINET วิชาการ ครั้งที่ 1 เรื่อง “Creative Library". กรุงเทพฯ : สำนักงานคณะกรรมการการอุดมศึกษา.

[5] ไตรรัตน์ ยืนยง และดิเรก ถึงฝั่ง. (2553). รูปแบบ การบริหารการเปลี่ยนแปลงของผู้บริหารโรงเรียน อาชีวศึกษาเอกชน. วารสารครุศาสตร์อุตสาหกรรม. ปีที่ 9 ฉบับที่ $2: 220$.

[6] มหาวิทยาลัยราชภัฏกำแพงเพชร. (2557). แผน ปฏิบัติราชการประจำปีงบประมาณ พ.ศ. 2557 สำนักวิทยบริการและเทคโนโลยีสารสนเทศ. สำนักวิทยบริการและเทคโนโลยีสารสนเทศ มหาวิทยาลัยราชภัฏกำแพงเพชร.

[7] กุลธิดา ท้วมสุข จุฑารัตน์ ศราวณะวงศ์ และกันยารัตน์ เควียเซ่น. (2554). รายงานการวิจัยเรื่อง รูปแบบ การบริหารห้องสมุดมหาวิทยาลัยที่ส่งเสริมการ เรียนรู้ของผู้เรียน. คณะมนุษยศาสตร์และสังคมศาสตร์ มหาวิทยาลัยขอนแก่น.

[8] สำนักงานอุทยานการเรียนรู้. (2556). อ่านเขา อ่านเรา. กรุงเทพ : สำนักงานบริหารและพัฒนา องค์ความรู้ (องค์การมหาชน). 